\title{
Analyzing the impact of wind generation on the transient stability
}

- Phan Thi Thanh Binh

Ho Chi Minh city University of Technology, VNU-HCM, Vietnam

- Ho Ngoc Thien

Power Engineering Consulting Joint Stock Company 2, Vietnam

(Manuscript Received on July 15, 2015, Manuscript Revised August 30, 2015)

\section{ABSTRACT}

The wind generation causes some troubles on the stability of power network. Observing the critical clearing time of circuit breaker with existence of wind generation, one conclusion about the degrading of

Keywords: Wind Generator, CCT, transient stability, penetration level.

\section{INTRODUCTION}

With the high level of wind generation, the power system stability in small and large disturbances must be considered [1] [2]. One of the reasons is that there is no exited wind for wind generator (WG). To build up the field, wind generator will absorb the reactive power from the network. For the fixed speed generator, when the short circuit occurs near the generator, due to the low voltage of network, a large amount of Q will be flowed into the generator. This causes the more decreasing of voltage and lowers the stability of network. For DFIGs, this situation is improved by the converters.

Many works focused on the critical clearing time. The most widely methods are based on the changing clearing time until the network loses its stability during short circuit as in [3] [4] using some soft- wares. Other works were concentrated on finding the appropriate models of wind generators in stability studies [5] [6]. Some works focused on the analytical analysis assuming that stability will be drawn. The location and the penetration level of this generation are also considered in this paper. The 14 buses IEEE network is examined with the soft ware PSAT. the voltage at the wind generator bus is invariant [7] .

This paper will mentioned the overall aspects of network transient stability with the existence of wind generation such as the influence on the critical clearing time (CCT), the location and the allowable penetration of wind generation.

\section{WAYS TO EXAMING STABILITY}

\subsection{CCT}

When one short circuit occurred, the CCT is the maximal time for fault clearing that the network still maintains its stability. For very simple system, CCT can be determined by analytical analysis. But for the net work with many buses, this approach is impossible. With the use of some soft- ware, for each fault, by changing the clearing time of corresponding breakers, we can get CCTs.

2.2 Wind generation and transient stability 
The impacts of WG on the stability network are expressed through CCTs. That means if for the same short circuit, with the WG, the CCTs are increased, the stability is better. On contrary, it can say that the stability is worsening.

First, the CCTs are determined without any WG, this is the base case. Using the PSAT [8], by increasing the time of short circuit clearing with the time step of $1 \mathrm{~ms}$, the CCT will be recorded. On the view of stability, some weak bus will be found with the smallest CCT. We will focus on this bus and its neighbors. Replacing the synchronous generator at these buses by WG with the same power injection, the stability estimation will be made.

The WG location can influence on the CCTs. The different locations for WG are examined with the same short circuits and the conclusion about the best location can be drawn.

With the existence of synchronous generator and WGs, the proper sharing injected power may enhance the stability. The penetration level of WG is also necessary for utility in exploiting its network.

\section{CASE STUDY}

The 14 buses IEEE network (Figure 1) will be examined [9]. The model of WG is mentioned in PSAT and the wind model is the Weibul distribution. For each line, two three short circuits will occur, near its ends.

\subsection{Case 1: The base case}

With no WGs, the worst case happened with the faults near the bus 2, exceptionally the fault on the line $2-3$ is more dangerous from the view of the stability. Bus 2 is the weak nest for stability aspect (Table 1). So the further examining will focus on the faults at neighbor buses of bus 2 .

3.2 Case 2: WG is located at one bus to replace the generator at bus 2
The following study estimates the impacts of wind generation injected at some bus with its feeders connecting to bus 2. Firstly, the WG will be installed at bus 2 . The synchronous generator will be replaced by the wind generator with the same power injection at this bus.

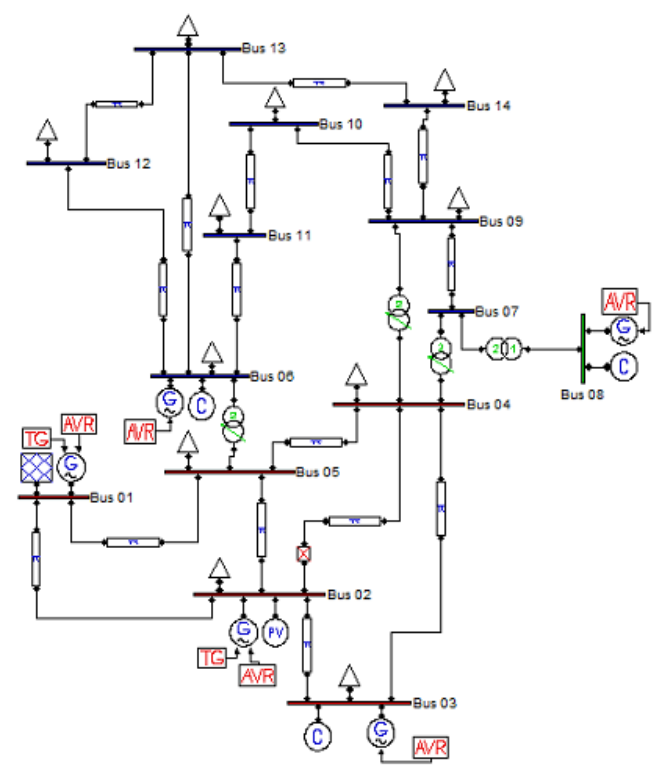

Figure 1 The 14 buses IEEE network

Table 1-The CCTs of the base case and the case with WG at bus 2

\begin{tabular}{|c|c|c|c|}
\hline \multirow{2}{*}{$\begin{array}{c}\text { Fault } \\
\text { near } \\
\text { the } \\
\text { bus }\end{array}$} & \multirow{2}{*}{$\begin{array}{c}\text { On the line } \\
\text { (connected two } \\
\text { buses) }\end{array}$} & \multicolumn{2}{|c|}{$\operatorname{CCT}(\mathrm{ms})$} \\
\hline & & Base case & $\begin{array}{c}\text { WG at bus } \\
2\end{array}$ \\
\hline 2 & $2-1$ & 353 & \\
\hline 2 & $2-3$ & 397 & 394 \\
\hline 2 & $2-4$ & 403 & 400 \\
\hline 2 & $2-5$ & 436 & 435 \\
\hline 3 & $3-2$ & 548 & 517 \\
\hline 3 & $3-4$ & 532 & 498 \\
\hline 4 & $4-2$ & 607 & 534 \\
\hline 4 & $4-3$ & 624 & 527 \\
\hline 4 & $4-5$ & 633 & 524 \\
\hline 5 & $5-1$ & 632 & 539 \\
\hline 5 & $5-2$ & 613 & 534 \\
\hline 5 & $5-4$ & 610 & 538 \\
\hline
\end{tabular}


In comparison with the base case, all CCTs are decreased and that means the DG degraded the stability of system

For more information about the impact on stability, the wind generator will be installed at other buses. The detail results for the case with wind generation or the synchronous generator at bus 4 are presented in Table 2 and Figure 2.

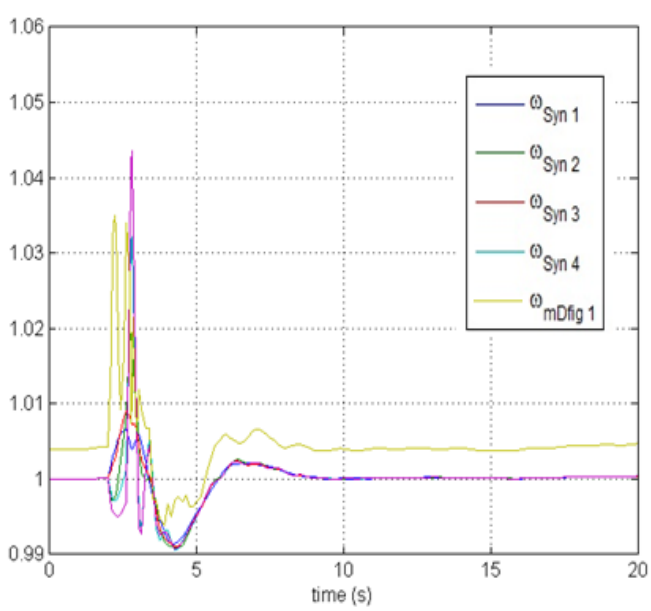

Figure 2-a. Rotor speeds when fault at Bus 3, line $3-2, \mathrm{CCT}=\mathrm{c}=475 \mathrm{~ms}$ and $\mathrm{WG}$ at bus 4

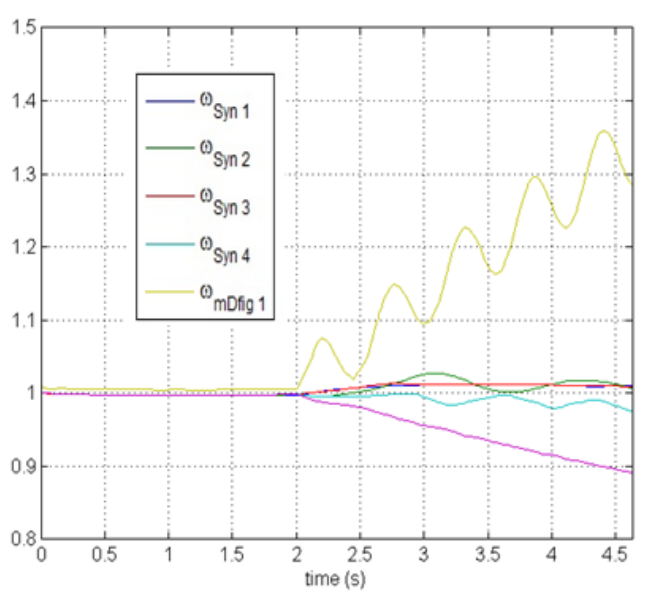

Figure 2-b. Rotor speeds when fault at Bus 3, line $3-2, \mathrm{CCT}=\mathrm{c}=476 \mathrm{~ms}$, WG at bus 4 .
Table 2. The CCTs of the case with synchronous generator and WG at bus 4

\begin{tabular}{|c|c|c|c|}
\hline \multirow{2}{*}{$\begin{array}{c}\text { Fault } \\
\text { near } \\
\text { the } \\
\text { bus }\end{array}$} & \multirow{2}{*}{$\begin{array}{c}\text { On the line } \\
\text { (connected } \\
\text { two buses) }\end{array}$} & $\begin{array}{c}|c| \\
\text { Synchronous } \\
\text { generator }\end{array}$ & $\begin{array}{c}\text { Wind } \\
\text { generator }\end{array}$ \\
\hline 2 & $2-1$ & 383 & 351 \\
\hline 2 & $2-3$ & 434 & 357 \\
\hline 2 & $2-4$ & 417 & 400 \\
\hline 2 & $2-5$ & 443 & 409 \\
\hline 3 & $3-2$ & 549 & 475 \\
\hline 3 & $3-4$ & 533 & 477 \\
\hline 4 & $4-2$ & 330 & 329 \\
\hline 4 & $4-3$ & 323 & 322 \\
\hline 4 & $4-5$ & 341 & 340 \\
\hline 5 & $5-1$ & 633 & 552 \\
\hline 5 & $5-2$ & 614 & 540 \\
\hline 5 & $5-4$ & 611 & 537 \\
\hline
\end{tabular}

3.3 Case 3: The location of WG and the stability

Table 3. The CCTs of the base case and case 3

\begin{tabular}{|c|c|c|c|}
\hline \multirow{2}{*}{$\begin{array}{c}\text { Fault } \\
\text { near } \\
\text { the } \\
\text { bus }\end{array}$} & $\begin{array}{c}\text { On the line } \\
\text { connected two } \\
\text { buses })\end{array}$ & \multicolumn{2}{|c|}{ CCT(ms) } \\
\cline { 3 - 4 } & WG at bus 5 & WG at bus 2 \\
\hline 2 & $2-1$ & 347 & \\
\hline 2 & $2-3$ & 350 & 394 \\
\hline 2 & $2-4$ & 442 & 400 \\
\hline 2 & $2-5$ & 393 & 435 \\
\hline 3 & $3-2$ & 486 & 517 \\
\hline 3 & $3-4$ & 472 & 498 \\
\hline 4 & $4-2$ & 529 & 534 \\
\hline 4 & $4-3$ & 546 & 527 \\
\hline 4 & $4-5$ & 570 & 524 \\
\hline 5 & $5-1$ & 308 & 539 \\
\hline 5 & $5-2$ & 319 & 534 \\
\hline 5 & $5-4$ & 323 & 538 \\
\hline
\end{tabular}

Instead of $\mathrm{WG}$ at the bus 2, now WG is moving to bus 4 and to bus 5 . The results with WG at bus 4 are presented in Table 2. With the same 
injected power and the same faults as in the case 2, the CCTs for WG at bus 5 are presented in Table 3.

In comparison with the WG at bus 2 , almost the CCTs are smaller. The CCT are changed sharply when the fault occurred at bus 4 or 5 . Here the CCT changes are about $50 \%$. That means if wind generation is located at bus 4 (or 5), the clearing time must be adjusted to meet the stability.

\subsection{Case 4: Sharing the power injection}

Sharing the power injection between synchronous and wind generator leads to improving the stability. Now if at bus 4 (or 5) one wind generator of $20 \mathrm{MW}$ is installed, this one will share the 40MW with the synchronous at bus 2 . The results are shown in Table 4.

\subsection{Case 5: The penetration level of WG injection}

Suppose the synchronous generator at bus 2 and the wind generator is at bus 4 . Now we increased the WG power injection at bus 4 . The highest level of WG penetration happens when the $40 \mathrm{MW}$ of power injection is in the case 2 , where the synchronous generator at bus 2 did not inject any power. The injected power from WG will be increased from the $16 \mathrm{MW}$ to $24 \mathrm{MW}$. The CCTs are shown in Table 5

The conclusion is that increasing the level of WG power injection worsens the stability of power system.

With the given set of fault clearing time, with the given of wind generator location, there will be a certain allowable penetration level of this one from the view of transient stability.

Table 4 CCTs (ms) of sharing power

\begin{tabular}{|c|c|c|c|c|c|c|c|}
\hline $\begin{array}{l}\text { Fault near } \\
\text { the bus }\end{array}$ & On line & Base case & $\begin{array}{c}\text { WG at bus } \\
2\end{array}$ & $\begin{array}{c}\text { WG at bus } \\
4\end{array}$ & $\begin{array}{c}\text { WG at bus } \\
5\end{array}$ & $\begin{array}{c}\text { Sharing: DG at } \\
\text { bus } 4\end{array}$ & $\begin{array}{c}\text { Sharing: DG at } \\
\text { bus } 5\end{array}$ \\
\hline 2 & $2-1$ & 353 & & 351 & 347 & 466 & 450 \\
\hline 2 & $2-3$ & 397 & 394 & 357 & 350 & 447 & 406 \\
\hline 2 & $2-4$ & 403 & 400 & 400 & 442 & 569 & 529 \\
\hline 2 & $2-5$ & 436 & 435 & 409 & 393 & 551 & 551 \\
\hline 3 & $3-2$ & 548 & 517 & 475 & 486 & 548 & 553 \\
\hline 3 & $3-4$ & 532 & 498 & 477 & 472 & 562 & 567 \\
\hline 4 & $4-2$ & 607 & 534 & 329 & 529 & 608 & 630 \\
\hline 4 & $4-3$ & 624 & 527 & 322 & 546 & 626 & 638 \\
\hline 4 & $4-5$ & 633 & 524 & 340 & 570 & 635 & 667 \\
\hline 5 & $5-1$ & 632 & 539 & 552 & 308 & 627 & 627 \\
\hline 5 & $5-2$ & 613 & 534 & 540 & 319 & 627 & 625 \\
\hline 5 & $5-4$ & 610 & 538 & 537 & 323 & 654 & 634 \\
\hline
\end{tabular}


Table 5 CCTs (ms) for different level of WG penetration

\begin{tabular}{|c|c|c|c|c|c|c|c|}
\hline \multirow{2}{*}{$\begin{array}{c}\text { Fault Location: } \\
\text { Near the bus }\end{array}$} & \multirow{2}{*}{$\begin{array}{c}\text { Line (conecting } \\
\text { bus-bus) }\end{array}$} & \multirow{2}{*}{ Base case } & \multicolumn{5}{|c|}{ Penetration level of WG (MW) } \\
\cline { 4 - 8 } & & $\mathbf{1 6}$ & $\mathbf{1 8}$ & $\mathbf{2 0}$ & $\mathbf{2 2}$ & $\mathbf{2 4}$ \\
\hline 2 & $2-1$ & 353 & 472 & 469 & 466 & 466 & 464 \\
\hline 2 & $2-3$ & 397 & 452 & 450 & 447 & 445 & 444 \\
\hline 2 & $2-4$ & 403 & 575 & 573 & 569 & 569 & 569 \\
\hline 2 & $2-5$ & 436 & 561 & 556 & 551 & 548 & 543 \\
\hline 3 & $3-2$ & 548 & 555 & 552 & 548 & 543 & 540 \\
\hline 3 & $3-4$ & 532 & 568 & 566 & 562 & 560 & 557 \\
\hline 4 & $4-2$ & 607 & 616 & 611 & 608 & 607 & 606 \\
\hline 4 & $4-3$ & 624 & 632 & 638 & 626 & 624 & 622 \\
\hline 4 & $4-5$ & 633 & 639 & 630 & 635 & 633 & 632 \\
\hline 5 & $5-1$ & 632 & 633 & 629 & 627 & 626 & 624 \\
\hline 5 & $5-2$ & 613 & 635 & 654 & 627 & 623 & 619 \\
\hline 5 & $5-4$ & 610 & & & 654 & 651 & 645 \\
\hline
\end{tabular}

\section{CONCLUSION}

The existence of WG has some negative on the power system stability when the short circuit happens. The CCTs of network are decreased. With the given clearing time of circuit breakers, there is some level for WG power injection, beyond this level, the stability will be lost. This is important for designing and exploitation the network with WG. Proper sharing the load between WG and synchronous generator enhances the stability.

\section{Trang90}




\section{Phân tích ảnh hưởng của máy phát điện gió lên ổn định động hệ thống điện}

\section{- Phan Thị Thanh Bình}

Trường Đại học Bách Khoa - ĐHQG-HCM, Việt Nam

- Hồ Ngọc Thiện

Công ty tư vấn điện 2, Việt Nam

\section{TÓM TÁ̀T}

Máy phát điện gió gây nên một số vấn đề cho ổn định lưới điện. Quan sát thời gian cắt tới hạn của các máy cắt khi có sự hiện hữu của máy phát gió có thể rút ra được một kết luận về sự xấu đi của ổn định hệ thống. Vị trí và mức độ thâm nhập của máy phát điện gió trên quan điểm ổn định cũng sẽ được xem xét trong bài báo này. Mạng điện IEEE 14 nút được khảo sát dựa trên phần mềm PSAT.

Từ khóa: Máy phát điện gió, CCT, ổn định quá độ, mức độ thâm nhập.

\section{REFERENCES}

[1]. A. S. El Safty, B. M. Abd El Geliel and C. M. Ammar, Distributed Generation Stability during Fault Conditions, International Conference on Renewable Energies and Power Quality (ICREPQ'10), Granada (Spain), 23-25 March, 2010.

[2]. J.G. Slootweg, W.L. Kling, The impact of large scale wind power generation on power system oscillations, Electric Power Systems Research Vol. 67, p.9-20, 2003.

[3]. T. Ananthapadmanabha, A. D. Kulkarni, ManojKumar Pujar, H. Pradeep and S. Chetan, Rotor angle stability analysis of a distributed generator connected to distribution network, Journal of Electrical and Electronics Engineering Research Vol. 2(5), pp. 107-113, November, 2010.

[4]. B. Boussahoua and M. Boudour, Critical Clearing Time Evaluation of Power System with UPFC by Energetic Method , pp: 85-88,
Journal of electrical systems (JES), Special Issue No. 01, November, 2009.

[5]. Pablo Ledesma, and Julio Usaola, Doubly Fed Induction Generator Model for Transient Stability Analysis, Trans. On energy conversion, Vol 20, no. 2, pp.388-397, June, 2005.

[6]. A.D Hasen, T. Lund and H. Bindner, Reduced Model of Double Fed Induction Generator System for Wind Turbine Simulations, Wind Energy, 299-311, 2006.

[7]. Ahda Pionkoski Grilo, Alexandre de Assis Mota, An Analytical Method for Analysis of Large-Disturbance Stability of Induction Generators, IEEE Trans. on power system,Vol. 22, no. 4, pp.1861-1869, November, 2007.

[8]. PSAT version 2.0.0 $\beta 1$ User's Manual Guide.

[9]. "Power system test case archive" available at http://www.ee.washington.edu/research/pstca/ 